\title{
Effect of EDTA on the removal Cd from artificially contaminated water by Tradescantia fluminensis
}

\author{
Seydahmet $\mathrm{CAY}^{1^{*}}$, Mehmet Soner ENGIN ${ }^{2}$ \\ ${ }^{1}$ Department of Environmental Engineering, Faculty of Engineering, Giresun University, 28200 Gure, Giresun, Turkey \\ ${ }^{2}$ Department of Food Engineering, Faculty of Engineering, Giresun University, 28200 Gure, Giresun, Turkey
}

"Corresponding Author: seydahmet.cay@giresun.edu.tr

Received: 07.12.2018

Accepted: 19.12 .2018

\begin{abstract}
Heavy metal polluted water is a great threat to sustainable marine, agriculture and environment. Plants can have the naturalability to absorb essential metals in its tissues from water solution, and this ability of plants can be advantage to extract trace metals from the polluted water. In this study, $\mathrm{Cd}(\mathrm{II})$ accumulation and distribution in the Tradescantia fluminensis were investigated, with a focus on the role of ethylenediaminetetracetic acid (EDTA) as a chelating agent in hydroponics. The results showed that in plant, EDTA, addition to media produced the highest major increase in Cd(II) accumulation but significantly decreased biomass of the plant. Also the Enrichment Coefficient (EC) and Translocation Factor (TF) values were calculated to evaluate the removal efficiency of the EDTA. Based on higher BCF (9.95 $\pm 0.54-$ $12.06 \pm 0.40)$ and $\mathrm{TF}(1.03 \pm 0.11-1.27 \pm 0.10)$ values, the high $\mathrm{Cd}$ (II) accumulation in the stems and leaves indicated that Tradescantia fluminensis has the potential of hyperaccumulation under EDTA enhanced treatments in removal for Cd(II) contaminated water.
\end{abstract}

Keywords: Tradescantia fluminensis, cadmium, EDTA, water.

\section{Tradescantia fluminensis Bitkisi Kullanılarak Sulardan Cd Uzaklaştırılmasına EDTA'nın Etkisi}

\section{$\ddot{\mathbf{O} z}$}

Ağır metaller ile kirlenmiş sular sürdürülebilir tarım ve çevre için büyük bir tehdittir. Bitkiler, beslenmeleri için ihtiyacı olan elementleri sulardan bünyelerine alma yeteneğine sahiptir ve bitkilerin bu yeteneği, kirlenmiş sulardan ağır metalleri uzaklaştırmak için kullanılabilir. Bu çalışmada, Tradescantia fluminensis bitkisinin Cd(II) biriktirme ve bünyesindeki dağılımı incelenmiş ve etilen diamintetrasetik asit (EDTA) 'nınşelatlaştırıcı madde olarak bunlara etkisi araştırılmıştır. Sonuçta, EDTA'nın ortama ilave edilmesinin Cd(II) birikiminde yüksek artışa neden olduğu ancak bitkinin biyokütlesini önemli ölçüde azalttığı görülmüştür. Ayrıca, EDTA'nın giderim etkinliğini değerlendirmek için

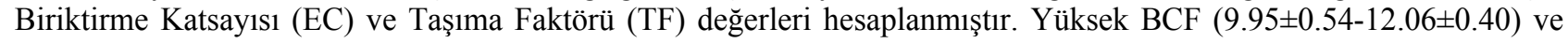
TF (1.03 $\pm 0.11-1.27 \pm 0.10)$ değerlerine bakılarak, gövde ve yapraklardaki yüksek Cd birikimi, Tradescantia fluminensis bitkisinin Cd(II) ile kirlenmiş sular için yardımcı kimyasal EDTA kullanıldığında hiperakümülatör bitki potansiyeline sahip olduğunu sonucuna varılmıştır.

Anahtar Kelimeler: Tradescantia fluminensis, Kadmiyum, EDTA, su. 


\section{Introduction}

Rapid increases in world population and industrialisation have seriously contributed to highly toxic heavy metal pollution in ecosystems. Due to the shortage of freshwater for irrigation, municipal and industrial sewage water is being used for irrigation in various countries including Turkey (Anwar et al., 2016).

Heavy metals are well known risk elements for the environment, and cadmium $(\mathrm{Cd})$ is the one of the most toxic of the heavy metals. Once in the water, $\mathrm{Cd}$ is highly persistent and maybe come available or uptake by fishes and plants and it is a threat to food security $(\mathrm{H}$. W. Liu, Wang, Ma, Wang, \& Shi, 2016). Phytoremediation refers to cleaning pollutants from contamined waters by plants, and it has attracted much attention since it is an environmentally friendly and relatively cheap technique (Cay, 2016; Sidhu, Singh, Batish, \& Kohli, 2017). Each plant species has different levels of tolerance toward different contaminants. The plants have evolved different mechanisms to maintain physiological collections of essential metals and to minimize exposure to nonessential heavy metals and to minimize the damage caused in plants by heavy metals (Bouchama, Rouabhi, \& Djebar, 2016; Cay, Uyanik, \& Engin, 2016). Excess Cd can interfere with numerous biochemical and physiological processes in plants by forming unspecific complex compounds in the cells. There is a need for the development of inexpensive and environmentally friendly new methods to extract heavy metals, thus improving water quality. Thanks to its cost effectiveness and environmentally friendly nature, phytoextraction (the use of green plants for remediation) of heavy metal contaminated water has become increasingly popular currently.

Spiderwort (Tradescantia fluminensis) is a monocotyledonous plant with soft fleshy leaves and a fleshy body belonging to the Commelinaceae family, native to southwestern Brazil and Northern Argentina.To date, spiderwort is also presented in Portugal, Italy, New Zealand, Russia, Japan, and south - eastern regions of Australia and USA, growing in damp and shaded places not like the bulk areas of forests but such as banks, parks, gardens, streamsides, and forest edges (R. Y. Liu et al., 2016). The aim of the present study was, therefore, to explore the Cd uptake capacity phytoremediation potential of Tradescantia fluminensis and effect of EDTA for Cd removal from wastewater. 


\section{Materials and methods}

\subsection{Experiment Design}

Tradescantia fluminensis seedling was used for this study. When the seedlings reached $10 \mathrm{~cm}$ in length and reached about $15 \mathrm{~cm}$ in length with mature roots, fidelities of similar shape and size were selected and washed three times with tap water to remove adhering particles. These plants were then used for experiments and separated into the beaker containing $100 \mathrm{ml}$ of the nutrient solution for 2 days preculture. The feed medium was a modified half-strength Hoagland nutrient solution (pH 5.5) made with the following salts (J. Y. Liu \& Schnoor, 2008). $1 \mathrm{mmol} \mathrm{L}^{-1} \mathrm{KNO}_{3}, 5$ mmol L ${ }^{-1} \mathrm{Ca}\left(\mathrm{NO}_{3}\right) \cdot 4 \mathrm{H}_{2} \mathrm{O}, 5 \mathrm{mmol} \mathrm{L}-1 \mathrm{KH}_{2} \mathrm{PO}_{4}, 2 \mathrm{mmol} \mathrm{L}^{-1} \mathrm{MgSO}_{4} \cdot 7 \mathrm{H}_{2} \mathrm{O}, 46.26 \mu \mathrm{mol} \mathrm{L}^{-1} \mathrm{H}_{3} \mathrm{BO}_{3}$, $9.15 \mu \mathrm{mol} \mathrm{L}{ }^{-1} \mathrm{ZnSO}_{4} \cdot 7 \mathrm{H}_{2} \mathrm{O}, 0.77 \mu \mathrm{mol} \mathrm{L}-1 \mathrm{MnCl}_{2} \cdot 4 \mathrm{H}_{2} \mathrm{O}, 0.32 \mu \mathrm{mol} \mathrm{L}{ }^{-1} \mathrm{H}_{3} \mathrm{MoO}_{4} \cdot \mathrm{H}_{2} \mathrm{O}, 0.12 \mu \mathrm{mol}$ $\mathrm{L}^{-1} \mathrm{CuSO}_{4} \cdot 5 \mathrm{H}_{2} \mathrm{O}, 20.01 \mu \mathrm{mol} \mathrm{L}{ }^{-1} \mathrm{FeSO}_{4} \cdot 7 \mathrm{H}_{2} \mathrm{O}, 20.03 \mu \mathrm{mol} \mathrm{L}{ }^{-1}$ EDTA-2Na$\cdot 2 \mathrm{H}_{2} \mathrm{O}$ ). Three rebuilds for each treatment with two Tradescantia fluminensis seedling in each beaker. The seven treatments were set as follows: Cd concentrations $\left(\mathrm{CdCl}_{2} .2 \mathrm{H}_{2} \mathrm{O}\right.$ (Merck, Germany) $(0,25,50$, and $100 \mathrm{mg} \mathrm{kg}^{-1}$ ) and EDTA concentrations (EDTA (Merck, Germany) (0.5, 1.0 and $1.5 \mathrm{mmolL}^{-1}$ ) (See table 1). The plants were harvested after being grown for 21 days. Plant samples were carefully washed, dried, separated and weighed into roots, stems and leaves.

Table 1. Concentrations of Cd and EDTA

\begin{tabular}{|c|c|c|c|c|c|}
\hline Treatment & $\begin{array}{c}\mathrm{Cd} \\
\left(\mathrm{mg} \mathrm{kg}^{-1}\right)\end{array}$ & $\begin{array}{c}\text { EDTA } \\
\left(\mathrm{mmol} \mathrm{kg}^{-1}\right)\end{array}$ & Treatment & $\begin{array}{c}\mathrm{Cd} \\
\left(\mathrm{mg} \mathrm{kg}^{-1}\right)\end{array}$ & $\begin{array}{c}\text { EDTA } \\
\left(\mathrm{mmol} \mathrm{kg}^{-1}\right)\end{array}$ \\
\hline $\mathrm{CO}$ & - & - & $\mathrm{EC0}$ & 25 & - \\
\hline $\mathrm{Cd} 1$ & 10 & - & ECd1 & 25 & 0.5 \\
\hline $\mathrm{Cd} 2$ & 25 & - & $\mathrm{ECd} 2$ & 25 & 1.0 \\
\hline $\mathrm{Cd} 3$ & 50 & - & $\mathrm{ECd} 3$ & 25 & 1.5 \\
\hline $\mathrm{Cd} 4$ & 100 & - & & & \\
\hline
\end{tabular}

E: EDTA, C0: Control

\subsection{Measurement methods}

After 21 days for hydroponics plants were harvested and divided into roots, stems and leaves. The separated pieces were then used to identify the accumulated Cd. Harvested plants were first washed with tap water and than washed with distilled water. The clean parts were dried in an oven at $70-80^{\circ} \mathrm{C}$ until constant weight was achieved. The dried plant samples were finely pulverized and their dry weights were measured. For the preparation of plant samples for analysis, microwave wet digestion technique was used. The aqueous phase was separated from the rest of the plant by centrifugation (Engin, Uyanik, Cay, \& Icbudak, 2010). The concentration of heavy metals in plant 
tissues was determined by a Bruker (820-MS) Inductive Coupled Plasma Mass Spectrometer (ICPMS).

\subsection{Data Analysis}

In addition to the cumulative concentration, BCF (Bioconcentration Factor) and $\mathrm{TF}$ (Translocation Factor) were used to assess the $\mathrm{Cd}$ accumulation capacity of Tradescantia fluminensis. BCF is the ratio of metal concentration to soil or water in the plant collection site (root, stem or leaf) (Zayed, Lytle, Qian, \& Terry, 1998). TF shows the ability to transport shoots defined as the ratio of the root of a plant to the concentration of metal in plant roots at plant roots (Mattina, Lannucci-Berger, Musante, \& White, 2003).

$\mathrm{BCF}=$ Dry weight $(\mathrm{dw}) \mathrm{Cd}$ concentration in plant tissue $/$ The initial concentration of $\mathrm{Cd}$ in the medium 2016).

$\mathrm{TF}=\mathrm{Cd}$ concentration in stem or leaf $(\mathrm{dw}) / \mathrm{Cd}$ concentration in root $(\mathrm{dw})$ (Chanu \& Gupta,

The metal concentrations of water and plants were reported as $\mathrm{mg} \mathrm{kg}^{-1}$ dry weight, and each result was the vehicle of three replicates. Anova was implemented with $\operatorname{SPSS}^{\circledR} 16.0$ statistical package Microsoft Excel $^{\circledR} 2010$ was used to draw the charts.

\section{Results and discussion}

$\mathrm{Cd}$ addition level of 10 and $50 \mathrm{mg} \mathrm{kg}^{-1}$ can be tolerated by Tradescantia fluminensis as there is a marginal decrease in the plant dry matter and no inhibitory symptoms appeared at this $\mathrm{Cd}$ addition level. As shown in Table 2, greater Cd addition into the water led to a significant decrease in plant dry matter. A similar trend was observed in plants treated with EDTA.

Table 2. Effects of Cd and EDTA on Tradescantia fluminensis dry weight

\begin{tabular}{|c|c|c|c|}
\hline Treatment & Dry weight (g) & Treatment & Dry weight (g) \\
\hline $\mathrm{C} 0$ & $1.67 \pm 0.37$ & $\mathrm{ECd} 0$ & $1.89 \pm 0.31$ \\
\hline $\mathrm{Cd} 1$ & $1.36 \pm 0.36$ & $\mathrm{ECd} 1$ & $1.22 \pm 0.28$ \\
\hline $\mathrm{Cd} 2$ & $1.89 \pm 0.31$ & $\mathrm{ECd} 2$ & $1.16 \pm 0.27$ \\
\hline $\mathrm{Cd} 3$ & $1.23 \pm 0.30$ & $\mathrm{ECd} 3$ & $1.08 \pm 0.25$ \\
\hline $\mathrm{Cd} 4$ & $1.05 \pm 0.33$ & & \\
\hline
\end{tabular}

E: EDTA, C0: Control (Values within the same column and followed by the same letter are not different at P $<$ 0.05 by an ANOVA-protected LSD test) 
$\mathrm{Cd}$ accumulation in plant increased significantly with increasing $\mathrm{Cd}$ concentration. The greatest $\mathrm{Cd}$ accumulation was observed when $100 \mathrm{mg} \mathrm{kg}^{-1} \mathrm{Cd}$ was applied (See Fig. 1).

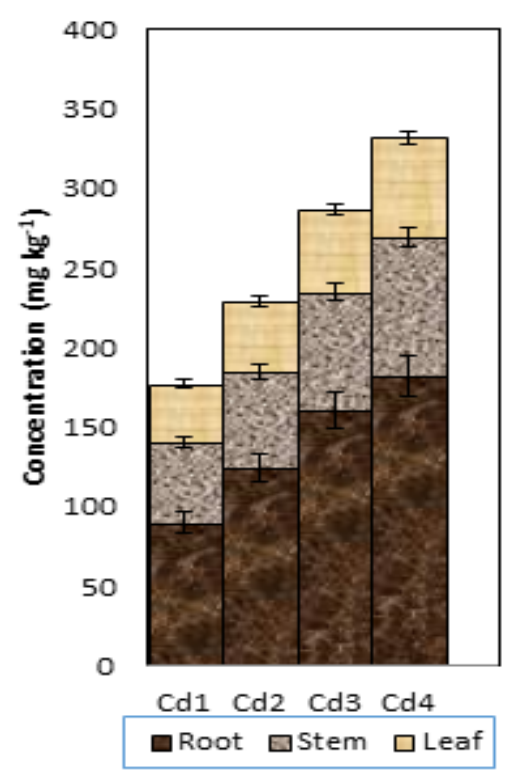

Figure 1. Concentration of $\mathrm{Cd}$ in root, stem and leaf of Tradescantia fluminensis.

It was found that plants supplemented with EDTA showed significantly greater uptake of Cd as compared to control plants without EDTA (See Fig. 2). This is because EDTA has the potential to mobilize $\mathrm{Cd}$ in the water and Cd-EDTA also absorbed by plants. $\mathrm{Cd}$ accumulation in roots was affected by EDTA so that the greatest accumulation was obtained when EDTA was applied. EDTA lead to a greater uptake of metals into the plant root and through the cell membrane.

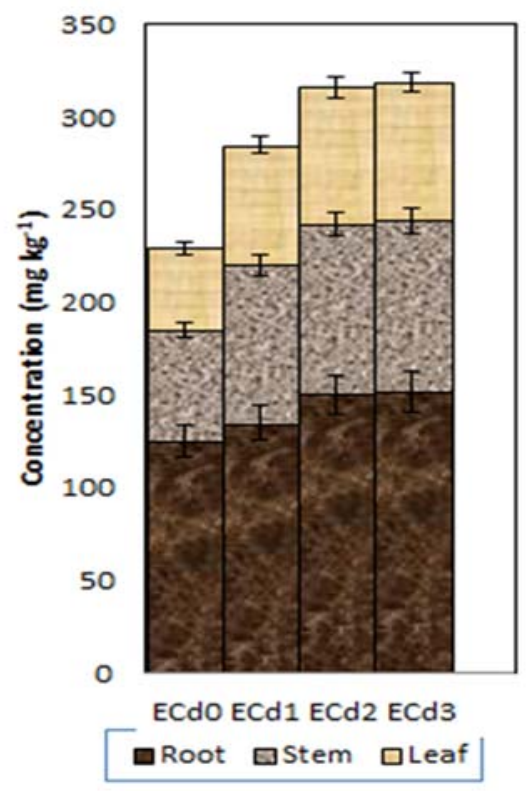

Figure 2. Comparison of Cd accumulation in each part of Tradescantia fluminensis with EDTA 
The Cd Bioconcentration Factor (BCF) and Translocation Factor (TF) of Tradescantia fluminensis was calculated by dividing the lead content in the various parts of the corn by the total Cd concentration in the $\mathrm{Cd}$ (See Table 3). The BCF values of $\mathrm{Cd}$ in the plant were lower if the water $\mathrm{Cd}$ concentrations were higher. The translocation factor (TF) values shown in Table 3 denote the ratio of the $\mathrm{Cd}$ concentration in the plant parts to that in the roots. The TF of the plant was the highest (1.27) when EDTA was added. TF values less than 1.0 indicate that a plant can tolerate $\mathrm{Cd}$ content, whereas TF values greater than 1.0 indicate that a plant is a $\mathrm{Cd}$ hyperaccumulator.

Table 3. Bioconcentration factors and Translocation Factors under different treatments

\begin{tabular}{|c|c|c|c|c|c|}
\hline Treatment & BCF & TF & Treatment & BCF & TF \\
\hline $\mathrm{Cd} 1$ & $11.17 \pm 1.47$ & $0.87 \pm 0.15$ & $\mathrm{ECd} 1$ & $9.95 \pm 0.54$ & $1.03 \pm 0.11$ \\
\hline $\mathrm{Cd} 2$ & $9.83 \pm 0.68$ & $0.80 \pm 0.12$ & $\mathrm{ECd} 2$ & $11.70 \pm 0.61$ & $1.15 \pm 0.14$ \\
\hline $\mathrm{Cd} 3$ & $7.85 \pm 0.42$ & $0.69 \pm 0.09$ & $\mathrm{ECd} 3$ & $12.06 \pm 0.40$ & $1.27 \pm 0.10$ \\
\hline $\mathrm{Cd} 4$ & $3.43 \pm 0.36$ & $0.52 \pm 0.10$ & & & \\
\hline
\end{tabular}

E: EDTA (Values within the same column and followed by the same letter are not different at $\mathrm{P}<0.05$ by an ANOVA-protected LSD test)

\section{Conclusion}

This study demonstrates the ability to store excess $\mathrm{Cd}$ in water and to store excess $\mathrm{Cd}$ in the stem and lower stem at high $\mathrm{Cd}$ exposure. The plant could well tolerate up to $100 \mathrm{mg} \mathrm{kg}^{-1} \mathrm{Cd}$ concentration levels, no visual symptom was observed in Tradescantia fluminensis. The plants with high efficiency for $\mathrm{Cd}$ accumulation may be exploited in extracting metals from polluted water individually or in combination with chaleting agent as EDTA based treatment system involving interdisciplinary approach.

\section{Acknowledgements}

This study was supported by Giresun University Scientific Research Project No: FEN-BAP-A160317-40.

\section{References}

Anwar, S., Nawaz, M. F., Gul, S., Rizwan, M., Ali, S., \& Kareem, A. (2016). Uptake and distribution of minerals and heavy metals in commonly grown leafy vegetable species irrigated with sewage water. Environmental Monitoring and Assessment, 188(9). 
Bouchama, K., Rouabhi, R., \& Djebar, M. R. (2016). Behavior of Phragmites australis (CAV.) Trin. Ex Steud used in phytoremediation of wastewater contaminated by cadmium. Desalination and Water Treatment, 57(12), 5325-5330.

Cay, S. (2016). Enhancement of cadmium uptake by Amaranthus caudatus, an ornamental plant, using tea saponin. Environmental Monitoring and Assessment, 188(6).

Cay, S., Uyanik, A., \& Engin, M. S. (2016). EDTA Supported Phytoextraction of Cd from Contaminated Soil by Four Different Ornamental Plant Species. Soil \& Sediment Contamination, 25(3), 346-355.

Chanu, L. B., \& Gupta, A. (2016). Phytoremediation of lead using Ipomoea aquatica Forsk. in hydroponic solution. Chemosphere, 156, 407-411.

Engin, M. S., Uyanik, A., Cay, S., \& Icbudak, H. (2010). Effect of the Adsorptive Character of Filter Papers on the Concentrations Determined in Studies Involving Heavy Metal Ions. Adsorption Science \& Technology, 28(10), 837-846.

Liu, H. W., Wang, H. Y., Ma, Y. B., Wang, H. H., \& Shi, Y. (2016). Role of transpiration and metabolism in translocation and accumulation of cadmium in tobacco plants (Nicotiana tabacum L.). Chemosphere, 144, 1960-1965.

Liu, J. Y., \& Schnoor, J. L. (2008). Uptake and translocation of lesser-chlorinated polychlorinated biphenyls (PCBs) in whole hybrid poplar plants after hydroponic exposure. Chemosphere, 73(10), 1608-1616.

Liu, R. Y., Dong, X. C., Gu, W. T., Yu, L. X., Jin, W. J., Qu, Y., . . Li, W. J. (2016). Variation in the phenotypic features and transcripts of thermo-sensitive leaf-color mutant induced by carbon ion beam in Green wandering jew (Tradescantia fluminensis). Scientia Horticulturae, 213, 303-313.

Mattina, M. I., Lannucci-Berger, W., Musante, C., \& White, J. C. (2003). Concurrent plant uptake of heavy metals and persistent organic pollutants from soil. Environmental Pollution, 124(3), 375-378.

Sidhu, G. P. S., Singh, H. P., Batish, D. R., \& Kohli, R. K. (2017). Tolerance and hyperaccumulation of cadmium by a wild, unpalatable herb Coronopus didymus (L.) Sm. (Brassicaceae). Ecotoxicology and Environmental Safety, 135, 209-215.

Zayed, A., Lytle, C. M., Qian, J. H., \& Terry, N. (1998). Chromium accumulation, translocation and chemical speciation in vegetable crops. Planta, 206(2), 293-299. 